\title{
Hillslope Erosion Mitigation: An Experimental Proof of a Nature-Based Solution
}

\author{
Ciro Apollonio $^{1} \mathbb{D}$, Andrea Petroselli ${ }^{2, *(\mathbb{D})}$, Flavia Tauro ${ }^{3} \mathbb{D}$, Manuela Cecconi ${ }^{4} \mathbb{D}$, Chiara Biscarini ${ }^{5} \mathbb{D}$, \\ Claudio Zarotti ${ }^{6}$ and Salvatore Grimaldi ${ }^{3}$
}

1 DAFNE Department, Tuscia University, 01100 Viterbo, Italy; ciro.apollonio@unitus.it

2 DEIM Department, Tuscia University, 01100 Viterbo, Italy

3 DIBAF Department, Tuscia University, 01100 Viterbo, Italy; flavia.tauro@unitus.it (F.T.); salvatore.grimaldi@unitus.it (S.G.)

4 DI Department, University of Perugia, 06125 Perugia, Italy; manuela.cecconi@unipg.it

5 SHeC Center Sustainable Heritage Conservation, Università per Stranieri di Perugia, 06123 Perugia, Italy; chiara.biscarini@unistrapg.it

6 PRATI ARMATI SRL, Opera, 20090 Milan, Italy; claudio.zarotti@pratiarmati.it

* Correspondence: petro@unitus.it

check for updates

Citation: Apollonio, C.; Petroselli, A.; Tauro, F.; Cecconi, M.; Biscarini, C.; Zarotti, C.; Grimaldi, S. Hillslope Erosion Mitigation: An Experimental Proof of a Nature-Based Solution. Sustainability 2021, 13, 6058. https://doi.org/10.3390/su13116058

\section{Academic Editors:}

Alejandro Gonzalez-Ollauri and Antonio Miguel Martínez-Graña

Received: 7 April 2021

Accepted: 26 May 2021

Published: 27 May 2021

Publisher's Note: MDPI stays neutral with regard to jurisdictional claims in published maps and institutional affiliations.

Copyright: (c) 2021 by the authors. Licensee MDPI, Basel, Switzerland. This article is an open access article distributed under the terms and conditions of the Creative Commons Attribution (CC BY) license (https:// creativecommons.org/licenses/by/ $4.0 /)$.

\begin{abstract}
Soil erosion during rainfall events is affected by several factors, such as topography, soil type, land management, and vegetation cover. In this study, a series of tests investigates the influence of selected perennial herbaceous plants with a deep and strong rooting system, called MC1, on runoff generation and soil erosion. The tests on the investigated nature-based solution have been performed in the Cape Fear experimental hillslope with natural and artificial rainfall and for different vegetation heights. For all the experiments, runoff, soil moisture, and erosion data were observed and collected. The results obtained in this study suggest the following conclusions: (1) MC1 is effective in terms of soil erosion reduction already with a minimum vegetation height equal to $30 \mathrm{~cm}$; (2) $\mathrm{MC1}$ maximum efficiency, in terms of soil loss reduction, has been reached for a vegetation height equal to $70 \mathrm{~cm}$; (3) In terms of the eroded material, the use of MC1 allows for a reduction of soil loss up to 300 times higher than the bare soil condition; (4) The use of MC1 allows for a reduction in the runoff coefficient up to $1 / 3$ of the corresponding value in the bare soil condition.
\end{abstract}

Keywords: land degradation; bioengineering techniques; soil erosion; runoff reduction; deep-roots herbaceous vegetation

\section{Introduction}

Soil is a key element in preserving ecosystems and biodiversity functions [1,2]. The Soil Thematic Strategy, established in Europe in 2006, highlighted the importance of policy measures to prevent land degradation and promote soil maintenance [3,4]. Moreover, in 2012, the European Commission identified priorities and guidelines to reach "no net land take by 2050" [5]. In addition, the United Nations have often recognized the importance of soil preservation [6] and identified the sustainable development goal (SDG) target 15.3 on land degradation [7].

Soil erosion is one of the main reasons of soil degradation, and is characterized by several negative impacts, both in agricultural areas [8] and in urban and peri-urban areas $[9,10]$. It causes serious long-term damages to arable lands and surrounding areas, such as fertility decrease, soil filtering reduction, change in soil infiltration and water absorption, loss of mineral fertilizers, and it increases the risk of landslides and floods [11-13]. It is also well known that the soil erosion process can severely damage civil infrastructures and their environment.

Soil erosion is mainly caused by natural phenomena, but it is accelerated and/or amplified by human factors, such as incorrect land planning, absence or poor maintenance 
of vegetation, action of mechanical means, and choice of unsuitable crops [14]. Therefore, erosion can be defined as a process of detachment and transport of soil materials by erosive agents from any part of the Earth's surface. Commonly, natural erosion is divided into two main categories: Water erosion and wind erosion. Water erosion, investigated here, occurs as different forms of splash, sheet and interrill erosion, rill erosion, gully erosion, river banks or channel erosion, tillage erosion, and glacial erosion. Sheet and interrill erosion can be considered one of the first steps of erosion in a watershed. In particular, it is widely observed on bare soils in agricultural lands and pasture [15].

Furthermore, it is difficult to mitigate soil erosion but such an effort is needed, as soil loss causes severe economic losses, estimated at USD 44 billion/year only in the USA, and damaged soil would take several hundred years to recover naturally $[2,16]$. Therefore, the development of techniques to reduce soil erosion is of paramount importance.

A typical soil conservation technique to decrease the effect of soil erosion is the construction of mechanical structures, such as back-slope, hedgerows, and slow-forming terraces [17-19]. Terracing is, indeed, probably the most popular practice and a classification as a function of their slope is available in [20], while in [21] an extensive review of functions, advantages, and disadvantages is provided. However, such interventions are often costly and labor intensive.

More recently, nature-based solutions (NBS) or bioengineering techniques have been established and proved that soil conservation techniques are more effective and less expensive than terracing [22-27]. NBS are characterized by the use of natural materials, usually live material often combined with dead or inert material, and are based on design choices and technical solutions to preserve the territory, environment, and landscape.

The use of NBS techniques has become popular in several areas of Europe, China, and North America [28,29], and more recently also in developing countries [26,27,30-32]. Indeed, the use of organic and biodegradable geotextiles for soil erosion reduction, erosion control, vegetation growth, and slope stabilization is rapidly evolving [33-41]. For example, Smets et al. [42] demonstrated that palm geotextiles reduce runoff coefficients and mitigate soil erosion in hillslopes, while Gimenez-Morera et al. [38] showed that cotton palm may limit soil erosion in Mediterranean climatic conditions. In addition, Vishnudas et al. [43] studied the use of coir geotextile on hillslopes to increase soil moisture availability. Moreover, jute is a good candidate for hillslopes protection, given its high hygroscopic property as shown by Tauro et al. [44], which assessed soil erosion reduction effectiveness in a steep slope by analyzing the performances of two biodegradable geotextiles based on jute. Although NBS proved to be significantly effective in reducing soil erosion, experimental studies performed in real-life conditions to accurately assess their effectiveness are limited. Smets et al. [45] performed a review on the ability of geotextiles in reducing runoff and soil erosion, based on laboratory studies, analyzing several factors, as plot length, cover percentage, slope gradient, rainfall duration and intensity, and geotextile type. Similar field and laboratory tests have been carried out by Kalibová et al. [46,47]. Field studies on jute and jute mats have been performed by Mitchel et al. [48] to demonstrate their effectiveness for controlling erosion and runoff. The use of palm geotextile mats was investigated in field experiments by Jankauskas et al. [49], observing a reduction in soil loss of over 90\%. Experimental observations coupled with soil erosion models are available in [41], which highlight the drawbacks of using laboratory tests to represent field conditions. Smets et al. [50] also implemented the effects of erosion-control blankets into the erosion numerical model using the European Soil Erosion Model [51].

A typical and more recent NBS technique consists of covering the hillslopes with specific vegetation species, which reduce the rainsplash, foster infiltration into the soil, slow down runoff, and improve the roots system to retain the soil, counteracting sliding downstream. Herbaceous vegetation guarantees optimal cover and shrub vegetation allows anchoring the soil to deeper layers. In any case, a careful evaluation of the species is required, preferring the selection of species that are compatible with the ecological characteristics of the intervention site. Indeed, autochthonous species are preferred with 
respect to exotic species that may alter the site ecological equilibrium $[27,30]$. Other than the anti-erosive and soil stabilizing actions, other benefits of the vegetation are the increase of the evapotranspiration capacity [23] and, in the case of particular plant species, the increase of soil shear strength.

While in the past grassy species have often been used and studied for the erosion control and mitigation, investigations related to the use of perennial vegetation characterized by deep-roots are limited. Such vegetation may represent an optimal, efficient solution for the soil erosion mitigation as well as for the improvement of equilibrium conditions of hillslopes [52,53]. Regarding the second point, two main effects have to be considered. The first effect concerns the positive role of roots acting as a mechanical soil reinforcement, from shallow to moderate depths. Moreover, at the ground surface, the roots provide a strong anchor for the epigeal plants portion avoiding its eradication in the case of extreme rainfall events and may reduce soil cracks. The second effect concerns the beneficial influence due to the reduction of soil water content/degree of saturation, due to the capacity of the plants to absorb water from the surrounding soil and transfer it to the atmosphere through transpiration. This mechanism, in turn, yields an increase in soil suction, in shear strength, and in soil protection against rainsplash and laminar erosion [53].

Different from trees and shrubs plantations that do not yield beneficial effects in mitigating soil erosion damage in the first few years of their growth, properly selected deep-rooting herbaceous plants are able to germinate, develop, and take roots very quickly, exhibiting their beneficial effects in a short time. In addition, these herbaceous species, mainly belonging to the botanical families of Gramineae and Leguminosae, can survive even in pedoclimatic and phytotoxic conditions prohibitive for more traditional vegetation [54].

In this paper, we present an experimental study with the aim to investigate the impact of a NBS, entailing the plantation of the deep-rooted species denoted MC1 (MC1 is an acronym. " $\mathrm{M}$ " stands for Macrotherma; "C" stands for C3-C4 carbon cycle; the number " 1 " indicates the first experimental tests held on Cape Fear with this type of plants) on runoff generation and soil erosion. The aim, in particular, is to assess the influence of MC1 height in mitigating hillslope erosion compared to the bare soil condition, and thus to identify at which height MC1 becomes efficient.

\section{Materials and Methods}

\subsection{Cape Fear Experimental Site}

The study was conducted in an experimental hillslope, named Cape Fear, located at Tuscia University in Viterbo, Central Italy. Cape Fear is a seminatural hillslope plot located in the outdoor experimental farm of Tuscia University, Viterbo, Italy $\left(42^{\circ} 25^{\prime} 28^{\prime \prime} \mathrm{N}\right.$, $12^{\circ} 04^{\prime} 44^{\prime \prime}$ E, $350 \mathrm{~m}$ a.s.l.). The plot consists of $30 \mathrm{~m}^{3}$ of natural wedge-shaped soil (44\% sand, $36 \%$ silt, $20 \%$ clay). Average values on five collected soil samples for laboratory-determined saturated water content, saturated hydraulic conductivity, organic content, and soil bulk density, are equal to $0.54 \mathrm{~m}^{3} / \mathrm{m}^{3}, 1.49 \mathrm{~cm} / \mathrm{min}, 0.58 \%$, and $10.1 \mathrm{kN} / \mathrm{m}^{3}$, respectively. In particular, sand, silt, and clay percentages were determined using standard laboratory techniques based on a set of sieves. The organic carbon content was determined with the dichromate method. The saturated water content was measured by the gravimetric method, whereas the saturated hydraulic conductivity was measured by the falling-head method. For a complete characterization of soil parameters, further details can be found in [55].

The wedge has a square area of $7 \times 7 \mathrm{~m}^{2}$, a slope of $17 \%$, and a maximum height of $1.2 \mathrm{~m}$ (Figure 1). The plot rests on a containment structure of wood boards and poles on three sides, and is founded on additional $10 \mathrm{~m}^{3}$ of soil disconnected from the underlying ground through a waterproof plastic layer. On a lateral side of the plot, a $2.5 \mathrm{~m}$-long glass panel has been installed for direct observation of water infiltration. Cape Fear allows conducting experiments both with natural and artificial rainfall. 


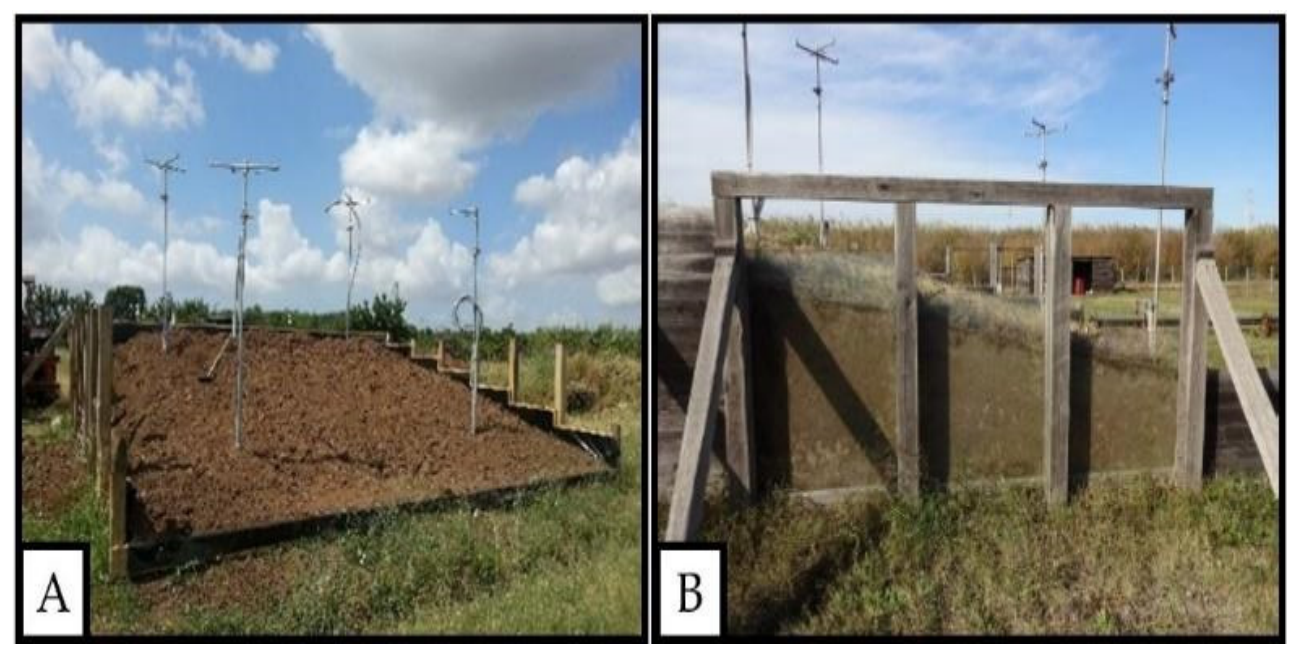

Figure 1. (A) Cape Fear hillslope plot: Frontal view; (B) glass panels.

In order to generate artificial rainfall, the plot surface hosts four pressurized nozzle rainfall simulators equipped with pressure probes [56,57]. Simulators were developed based on the prototype by Riley et al. [58]. Their structure includes a telescopic aluminum tripod connected to a steel plate. Three hoses are riveted to the plate and water is sprayed through a system of three nozzles. An HH7-M 3/4" in nozzle is mounted on the central hose, whereas two smaller HH22-M 3/8" in nozzles are placed onto the lateral hoses. Three cut-off valves allow for selectively activating the nozzles and controlling rainfall intensity. Rainfall intensities can be varied from a minimum of $40 \mathrm{~mm} \mathrm{~h}^{-1}$ using the two smaller nozzles to $140 \mathrm{~mm} \mathrm{~h}^{-1}$ by operating the three nozzles simultaneously. Conversely, regarding its use in natural rainfall condition, rainfall data are monitored through four SBS-500 Campbell Scientific standard rain gauges located at $30 \mathrm{~m}$ from the plot at the vertices of the nearby "giant-rain gauge" apparatus described in [59].

Cape Fear soil moisture is monitored through four Campbell Scientific CS615 water content reflectometers. They are located within an undisturbed $4 \times 4 \mathrm{~m}^{2}$ area and aligned along the downslope direction in the center of the plot. A pair of shallow reflectometers is located at $10 \mathrm{~cm}$ and the other deep pair at $50 \mathrm{~cm}$ below the soil surface.

The surface and subsurface runoff are collected in a v-shaped aluminium channel located along the downstream side of the plot. The channel pours water and solids into an aluminium tank composed of three connected partitions, where a stainless steel OBS-3+ turbidity sensor and a structural testing system (STS) strain gauge are hosted. A coarser solid material is blocked in the first partition of the tank. Flow discharge exits the tank through a v-notch weir and an output liquid discharge is computed from the water level thanks to a calibrated stage-discharge relationship. Monitored parameters are sampled at $1 \mathrm{~Hz}$, then averaged at $5 \mathrm{~min}$ resolution, and stored on a CR10X Campbell Scientific data logger. Detailed soil characterization of the plot along with the calibration of turbidity and water level sensors are provided in $[55,60]$.

\subsection{Vegetation Cover}

Graminaceous perennial deep-root species, here denoted $\mathrm{MC1}$, were implanted at Cape Fear, which are non-GMO and characterized as adaptable to all soil types and extreme climatic conditions ( $\mathrm{pH} 3 / 11$; temperature $-40^{\circ} \mathrm{C} /+60^{\circ} \mathrm{C}$ ). Their root depth combined with the specific plants' physiology allow surviving in extreme drought conditions. Regarding the root-system features, a complete growth in 24 months and root diameters ranging from 0.1 to about $3 \mathrm{~mm}$ are expected.

The adopted root-system is characterized by roots with a very large tensile strength (of about tens of $\mathrm{MPa}$ ), enhancing the increase in shear strength of the rooted soil. It is well known that this directly depends on the root area ratio (RAR), the soil friction angle, as well as a non-dimensional empirical factor $[53,61-64]$. The RAR quantity represents the ratio 
between the roots' cross section and the rooted soil cross section. The RAR ratio typically decreases with depth, this occurrence is generally verified despite the complex geometry of the root system that presents a great variability depending not only on plant species, soil properties and profile, but also on climatic and environmental conditions $[65,66]$.

Due to such intrinsic variability, the evaluation of the RAR requires careful attention. In the past, there were experiences of plants that were introduced due to their efficacy in soil erosion control, but were then recognized as invasive, for example, see Kudzu (Pueraria montana var. lobata) in the southeastern United States [67]. For this reason, it is important to specify that, although the experimental period did not last long, the MC1 spread has not been detected next to the experimental hill. The past use of this species in Italy for the last decades supports this point.

\subsection{Experimental Setup}

In the first phase of research, the Cape Fear surface was in a bare soil condition, the most critical scenario in terms of soil erosion (see Figure 1). Subsequently, starting from July 2020, MC1 was sown on half of the Cape Fear surface, as shown in Figure 2. Before illustrating the tests plan, in this section, we provide a step-by-step description of the Cape Fear grassing process using MC1.

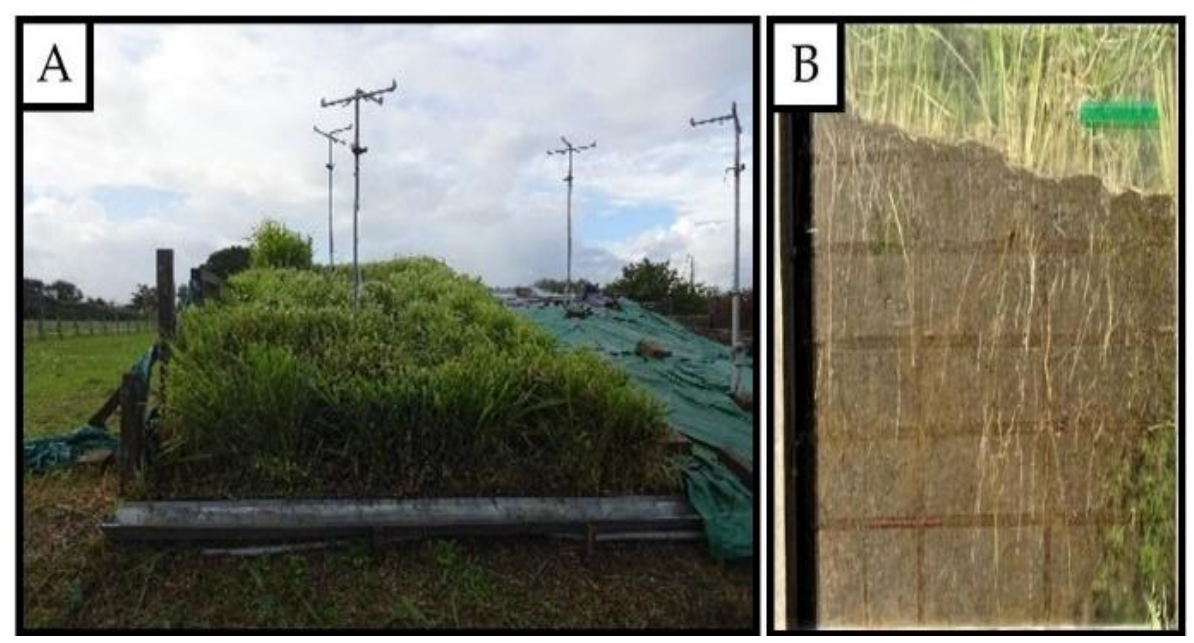

Figure 2. Cape Fear hillslope plot: (A) Vegetated side, (B) view of roots within the soil.

The preliminary step consisted of completely weeding the experimental hill. Ten days after, the half parcel (Figure 2A) was covered with a mulch cloth. In this way, the land would have not been irrigated, it would have been protected against wind and rainfall erosion, and the spontaneous vegetation growth would have been prevented.

Then, half of the Cape Fear surface was plowed and sown with MC1 (Figure 2A). During this phase, MC1 was irrigated three times for a day, for a total of about $101 / \mathrm{m}^{2}$. The irrigation phase of the "cultivated land" lasted for 30 days. At the end of this phase, plants first began to sprout and the irrigation has been reduced to one time for a day, in the same amount as before. This irrigation helped promote the MC1 root vertical development. In fact, in this way, the roots are forced to seek water in depth.

After the experimental hill preparation, tests have been planned and executed. Specifically, the following four tests have been investigated: Test no. 1 corresponds to the bare soil (vegetation height, denoted with $\mathrm{h}_{\mathrm{MC}}$, equal to zero); test no. 2 corresponds to a vegetation height of about $30 \mathrm{~cm}$; test no. 3 corresponds to a vegetation height of about $70 \mathrm{~cm}$; test no. 4 corresponds to a vegetation height of about $140 \mathrm{~cm}$. The four tests have been investigated using natural and artificial rainfall with characteristics, as shown in Table 1. 
Table 1. Rainfall characteristics during the four tests.

\begin{tabular}{|c|c|c|c|c|c|}
\hline Test & $\mathrm{h}_{\mathrm{MC1}}(\mathrm{cm})$ & Rainfall Type & $\begin{array}{c}\text { Cumulative Rainfall } \\
\text { Value (mm) }\end{array}$ & $\begin{array}{c}\text { Max Rainfall } \\
\text { Intensity }(\mathrm{mm} / \mathrm{h})\end{array}$ & $\begin{array}{c}\text { Rainfall Duration } \\
\text { (Wet Period) (h) }\end{array}$ \\
\hline \multirow{2}{*}{ No. 1} & \multirow[b]{2}{*}{0} & - & - & - & - \\
\hline & & Artificial & 680 & 170 & 4 \\
\hline \multirow{2}{*}{ No. 2} & \multirow[b]{2}{*}{30} & Natural & 121 & 42.6 & 42.1 \\
\hline & & Artificial & 3360 & 140 & 24 \\
\hline \multirow{2}{*}{ No. 3} & \multirow{2}{*}{70} & Natural & 70 & 92.2 & 12.9 \\
\hline & & Artificial & 4080 & 170 & 24 \\
\hline \multirow{2}{*}{ No. 4} & \multirow{2}{*}{140} & Natural & 110 & 141.8 & 17.5 \\
\hline & & Artificial & 3840 & 160 & 24 \\
\hline
\end{tabular}

\section{Results and Discussion}

During the four tests, data were collected following the procedure described in Figure $3 \mathrm{C}$. Here, results are illustrated focusing on the MC1 effect specifically on the rainfall-runoff hillslope response and soil erosion.

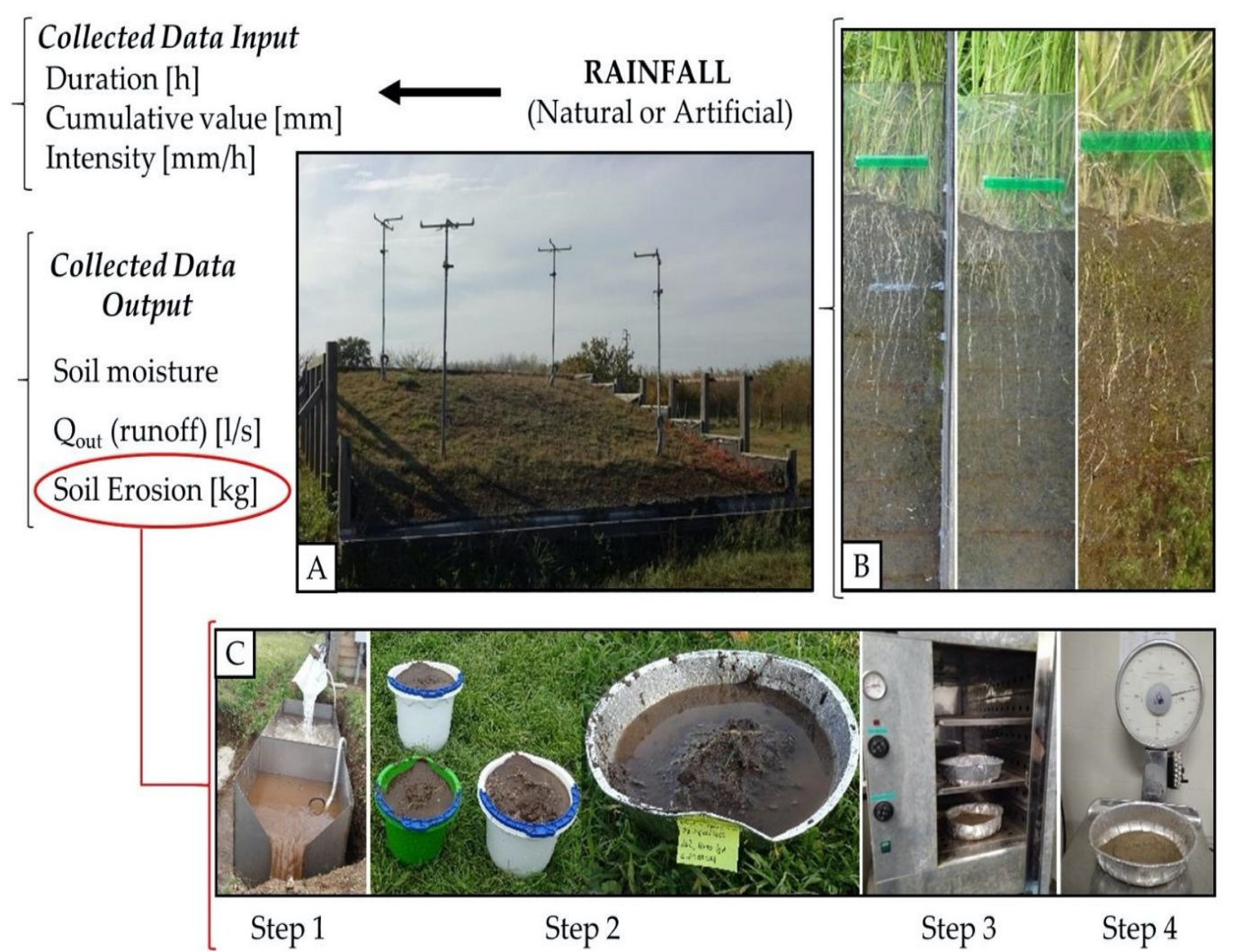

Figure 3. Description of data collection. (A) View of the experimental plot. (B) Detail of root growth monitoring. (C) Description of soil erosion measurements: Step 1: The tank for sedimentation of eroded material; Step 2: The eroded material; Step 3: Detail of drying in the oven at $110^{\circ} \mathrm{C}$ for $24 \mathrm{~h}$; Step 4: Final weighing of eroded material.

\subsection{Runoff Hillslope Response}

First, the natural rainfall condition has been analyzed. Figure 4 represents the input (natural rainfall) and output (runoff) time series that occurred in the different conditions of vegetation height. Considering the cumulative values for rainfall and runoff, the detected runoff coefficients were $0.05\left(\mathrm{~h}_{\mathrm{MC} 1}=30 \mathrm{~cm}\right), 0.46\left(\mathrm{~h}_{\mathrm{MC} 1}=70 \mathrm{~cm}\right)$, and $0.92\left(\mathrm{~h}_{\mathrm{MC} 1}=140 \mathrm{~cm}\right)$. From a theoretical point of view, we were expecting a lower runoff coefficient value for the 
increasing vegetation height. The obtained results could be due to the high values of soil moisture that were recorded in all the tests, and above all to the different rainfall intensities that occurred during the "natural" tests. Indeed, unfortunately a higher intensity was registered with a higher vegetation, and therefore, probably, mitigating the MC1 efficiency.

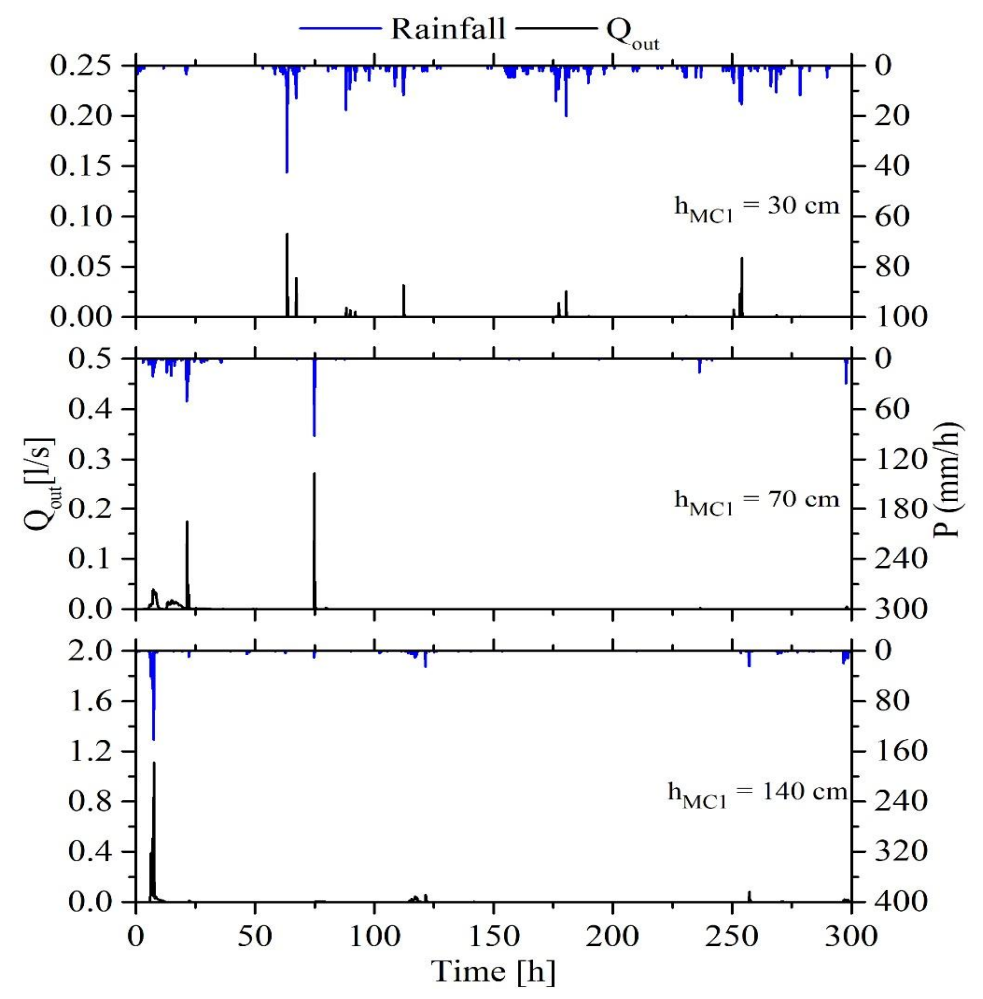

Figure 4. Natural rainfall and runoff for different MC1 vegetation heights.

In order to deeply investigate this aspect, specific rainfall events were analyzed (see Figure 5). In particular, for every test, three rainfall events have been selected from the complete timeseries shown in Figure 4, including the available maximum intensity storms (i.e., the third row in Figure 5).

As reported in Table 2, for low rainfall intensity events, MC1 may allow a relevant reduction of the runoff coefficient. For events characterized by a higher rainfall intensity (greater than $40 \mathrm{~mm} / \mathrm{h}$ in terms of rainfall peak or $20 \mathrm{~mm} / \mathrm{h}$ in terms of average rainfall intensity), the runoff coefficient increases and tends to 1 , a circumstance that was achieved for event no. 3 with a vegetation height of $140 \mathrm{~cm}$, where more than $56 \mathrm{~mm}$ of cumulative rainfall occurred in $2.67 \mathrm{~h}$, and with a rainfall peak greater than $140 \mathrm{~mm} / \mathrm{h}$.

Table 2. Runoff coefficient during isolated natural rainfall events.

\begin{tabular}{|c|c|c|c|c|c|c|c|}
\hline $\mathrm{h}_{\mathrm{MC1}}(\mathrm{cm})$ & $\begin{array}{l}\text { Event } \\
\text { Number }\end{array}$ & $\begin{array}{l}\text { Average Rainfall } \\
\text { Intensity }(\mathrm{mm} / \mathrm{h})\end{array}$ & Duration (h) & $\begin{array}{c}\text { Cumulative } \\
\text { Rainfall (mm) }\end{array}$ & $\begin{array}{c}\text { Max Rainfall } \\
\text { Intensity }(\mathrm{mm} / \mathrm{h})\end{array}$ & $\begin{array}{c}\text { Runoff } \\
\text { Coefficient (-) }\end{array}$ & $\begin{array}{l}\text { Lag Time } \\
\text { (min) }\end{array}$ \\
\hline \multirow{4}{*}{30} & 1 & 2.01 & 0.75 & 1.51 & 3.55 & 0.45 & 40 \\
\hline & 2 & 2.69 & 1.42 & 3.81 & 4.73 & 0.64 & 70 \\
\hline & 3 & 6.17 & 1.83 & 11.31 & 42.55 & 0.93 & 40 \\
\hline & 1 & 6.57 & 0.67 & 4.38 & 29.55 & 0.08 & 30 \\
\hline \multirow[t]{3}{*}{70} & 2 & 16.63 & 1.08 & 18.02 & 50.83 & 0.28 & 25 \\
\hline & 3 & 22.59 & 0.67 & 15.06 & 92.16 & 0.30 & 15 \\
\hline & 1 & 8.04 & 0.33 & 2.68 & 26.00 & 0.37 & 15 \\
\hline \multirow[t]{2}{*}{140} & 2 & 2.83 & 5.25 & 14.84 & 10.64 & 0.38 & 125 \\
\hline & 3 & 21.24 & 2.67 & 56.64 & 141.84 & 1.00 & 20 \\
\hline
\end{tabular}




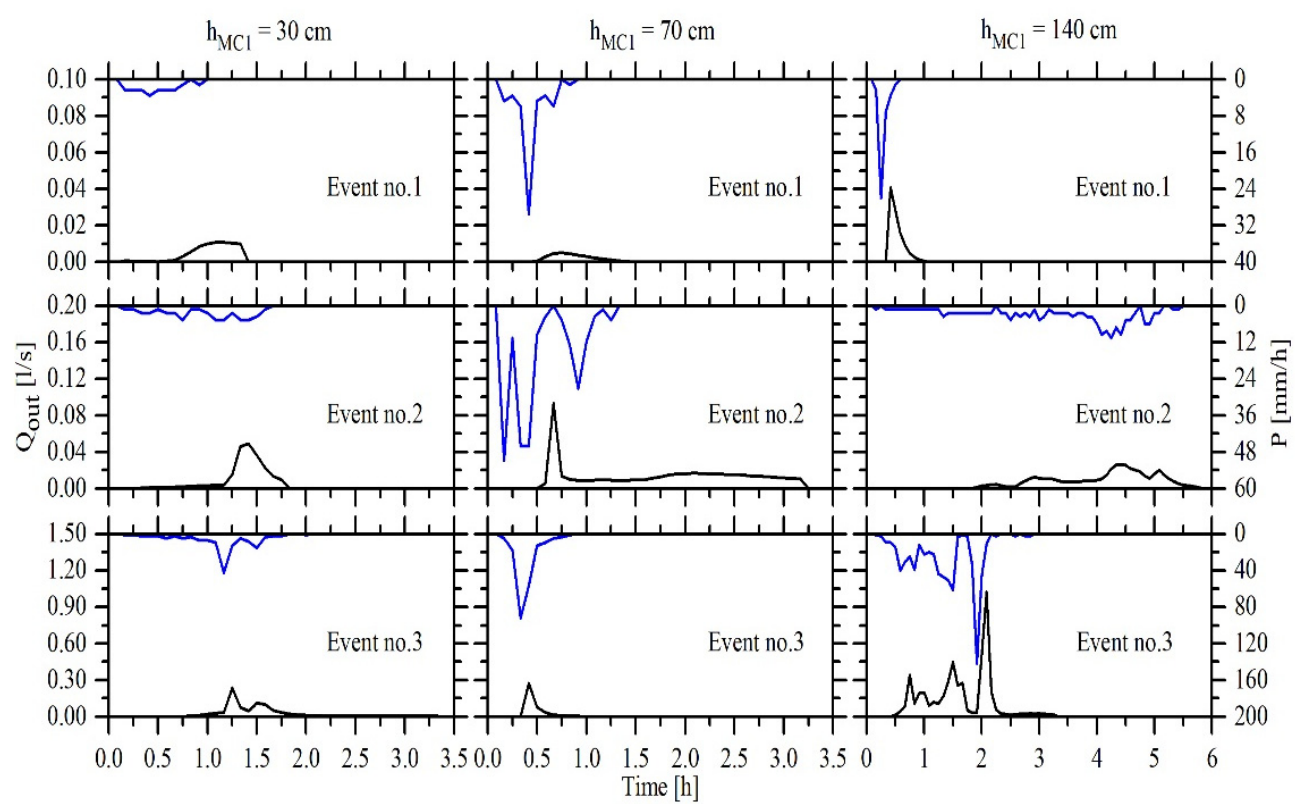

Figure 5. Isolated natural rainfall (blue line) and runoff (black line) for different MC1 vegetation heights $\left(\mathrm{h}_{\mathrm{MC} 1}\right)$.

A similar behavior has been detected in terms of lag time, i.e., the time difference between the rainfall start and the runoff start.

The MC1 effect on runoff coefficient has been investigated also for the artificial rainfall test, in which being approximately constant in time and similar for the four tests allows a better overview of the analyzed phenomena. The high simulated rainfall intensities (Table 1) do not allow investigating the lag time since it is too short for all the tests.

Figure 6 shows the rainfall-runoff data observed in the four tests. The local input flow rate variability, clearly visible in all the tests except for the vegetation height equal to $140 \mathrm{~cm}$, depends on the experimental farm hydraulic network that could not guarantee a constant rainfall intensity and on the variable windy condition (observed in test no. 4).

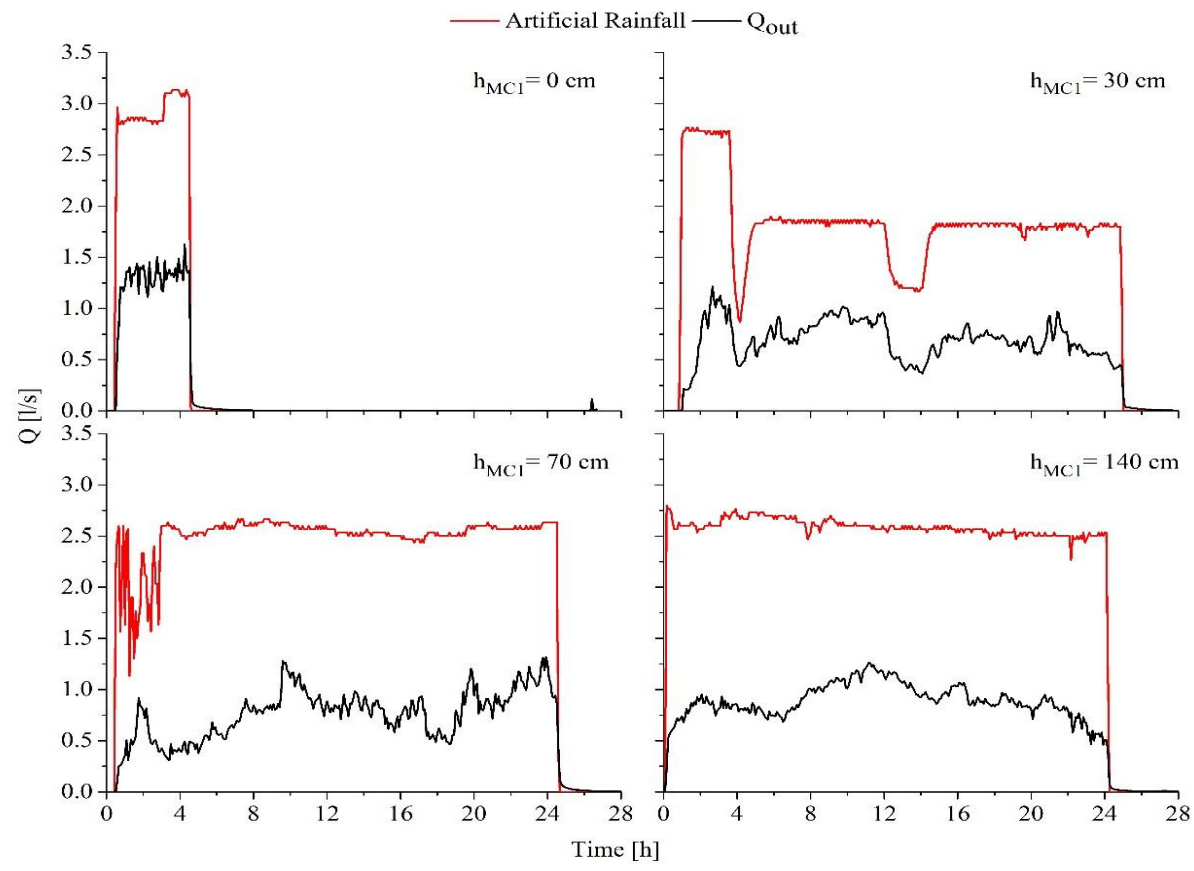

Figure 6. Artificial rainfall and output discharge for different $\mathrm{MC} 1$ vegetation heights $\left(\mathrm{h}_{\mathrm{MC}}\right)$. 
Table 3 reports the runoff coefficient values estimated on the four tests and confirms that it decreases while increasing the MC1 height. While the reduction is negligible for configuration $2(\mathrm{~h}=30 \mathrm{~cm})$, it is becoming relevant for $\mathrm{h}=70 \mathrm{~cm}$ reaching the $30 \%$ respect to the bare soil condition.

Table 3. Runoff coefficient for artificial rainfall tests.

\begin{tabular}{cccc}
\hline $\mathbf{h}_{\mathbf{M C 1}} \mathbf{( c m )}$ & $\begin{array}{c}\text { Test Rainfall } \\
\text { Intensity }(\mathbf{m m} / \mathbf{h})\end{array}$ & Test Duration (h) & Runoff Coefficient (-) \\
\hline 0 & 170 & 4 & 0.50 \\
\hline 30 & 140 & 24 & 0.49 \\
\hline 70 & 170 & 24 & 0.36 \\
\hline 140 & 160 & 24 & 0.34 \\
\hline
\end{tabular}

\subsection{Soil Erosion}

Figure 7 shows the ratio between the eroded soil amount and the rainfall volume observed in the four tests. It is noteworthy that, in the artificial rainfall conditions, the test in the bare soil configuration (test no. 1) was interrupted after $4 \mathrm{~h}$ of rainfall due to the massive soil erosion (Table 1). Figure 7 clearly shows that the eroded soil material for the configuration of bare soil is impressively higher than the corresponding values obtained using "vegetated" configurations. In particular, from test no. 1 to 3 a soil erosion reduction (normalized on rainfall height) of about 300 times has been obtained, similar to the reduction observed for test no. 4 . These data confirm that the vegetation efficiency can be considered as maximum at $\mathrm{h}_{\mathrm{MC} 1}=70 \mathrm{~cm}$. Indeed, with $\mathrm{h}_{\mathrm{MC} 1}=30 \mathrm{~cm}$, we obtained a reduction in soil erosion, with respect to the bare soil, of about 35 times.

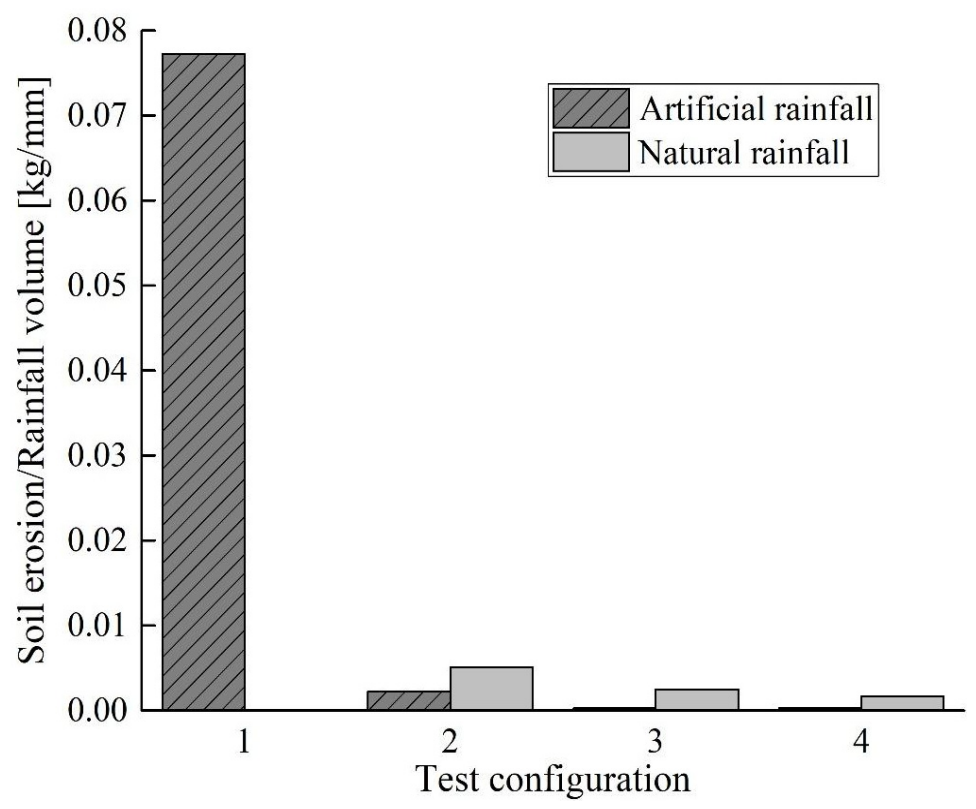

Figure 7. Ratio of eroded material $(\mathrm{kg})$ to cumulative rainfall value $(\mathrm{mm})$ for the four vegetation configurations, in artificial and natural rainfall conditions.

The obtained results are in line with recent studies that investigated the individual plant species effect on soil and water losses, documenting that plants control runoff generation and sediment production. For example, Chau and Chu [68] assessed the erosion-reducing potential of five native fern species of southern China (Blechnum orientale, Cyclosorus parasiticus, Dicranopteris pedata, Nephrolepis auriculata, and Pteris vittata). Each fern species reached two levels of cover (40 and $80 \%)$ in $1.0 \times 0.5 \mathrm{~m}^{2}$ soil 
boxes tilted to $50^{\circ}$, compared to the boxes with bare soil. The erosion control performance was tested using a computer-controlled pressurized rainfall simulator, which provided a rainfall intensity of $100 \mathrm{~mm} / \mathrm{h}$ to reflect a heavy rainstorm event. The high cover of ferns $(80 \%)$ reduced the runoff volume by $65.0 \%$ and sediment loss by $96.1 \%$ compared to the bare soil.

Significantly, the soil erosion reduction was detected by Stanchi et al. [69] across 6 years (with 12 natural events with sediment production) in a sloping vineyard located in Aosta Valley, equipped to assess the effect of different soil managements (permanent grassing, chemical weeding, and buffer strips). Moreover, the impact of mechanization on the sediment amounts and properties was assessed. Permanent grassing and buffering showed comparable effects, reducing soil erosion considerably. In fact, the average erosion rates ranged from negligible (mainly in grassed rows/buffering) to 1.1 ton/ha per event (after weeding). The tractor passage, dependent on the adopted soil management approach, visibly accelerated the erosion process. In this experiment, permanent grassing strongly reduced erosion (in most cases from 2 to 10 times, depending on the event characteristics).

The mitigation effect exerted with permanent grassing by Stanchi et al. [69] was therefore considerable and in agreement with our study and with the findings of Biddoccu [70], who reported a reduction of up to $90 \%$ of the erosion rate in rows with cover crops vs. conventional tillage in similar environments.

Moreover, Mohamadi and Kavian [71] observed a direct relationship of eroded material with rainfall kinetic energy, approximated by a non-linear equation. In order to verify such relationship, soil erosion has been related to the rainfall kinetic energy computed using the equation proposed by Wischmeier and Smith [72]:

$$
E=210.3+89 I
$$

where $E$ is the rainfall kinetic energy in $\mathrm{J} \mathrm{m}^{-2} \mathrm{~cm}^{-1}$, and $I$ is the intensity in $\mathrm{cm} \mathrm{h}^{-1}$.

The results obtained are listed in Table 4 . As it can be seen, the kinetic energy values are almost constant for the artificial tests, and this is due to the fact that we set the same rainfall characteristics.

Table 4. Eroded material and kinetic energy for the four tests.

\begin{tabular}{cccc}
\hline Test & Rainfall Type & Eroded Material (kg) & Kinetic Energy (JM $\mathbf{2}^{\mathbf{}}$ \\
\hline \multirow{2}{*}{ No. 1} & - & - & - \\
& Artificial & 52.51 & 320 \\
\hline \multirow{2}{*}{ No. 2} & Natural & 0.615 & 162 \\
& Artificial & 7.48 & 312 \\
\hline \multirow{2}{*}{ No. 3} & Natural & 0.195 & 191 \\
& Artificial & 1.12 & 320 \\
\hline \multirow{2}{*}{ No. 4} & Natural & 0.185 & 192 \\
& Artificial & 1.00 & 317 \\
\hline
\end{tabular}

The test with bare soil provides the highest value in terms of the eroded material. It is interesting to note that with the same kinetic energy, tests no. 3 and 4 substantially provide the same soil erosion values. Consequently, the relationship between the kinetic energy and eroded material does not fit a linear function, confirming the Mohamadi and Kavian [71] contribution.

The developed experimental tests suggest useful feedbacks for future analyses. Indeed, we are aware that further experiments are needed for statistically characterizing the obtained conclusions and for better trying to reproduce optimal rainfall patterns on the experimental plot. In addition, each test should be repeated several times in order to have a stable intensity rainfall and, if the stability is not reached for the full experiment duration, a minimum observation period could be considered as an optimal reference for the analyses. This will allow for a richer data set to explore the variability of the obtained results. 
As previously stated, this research represents the first experimental tests on this particular anti-erosive solution. These tests respond to the need to more deeply know the behavior of these bioengineering solutions. In Italy, the growing use of these techniques is confirmed by the very recent construction of the new Genoa-San Giorgio Bridge, where the banks were stabilized with NBS similar to the one tested in this research.

This work also fills the need to increase the investments for natural risk reduction/mitigation. In fact, following the coronavirus pandemic, the European Commission launched a comprehensive and ambitious recovery plan, where particular attention is given to investments in the field of naturalistic engineering and in the use of NBS for the mitigation of hydrogeological risk.

\section{Conclusions}

In this paper, we studied a nature-based solution for hillslope erosion mitigation. While the results concerning the runoff coefficient variation do not allow for a general conclusion to be reached, suggesting a reduction of $30 \%$ in the case of vegetated hillslope limited to the artificial rainfall case, the soil erosion reduction results are clear and promising. Indeed, a consistent decrease of the eroded material (up to 300 times) was observed compared to the investigated vegetation cover (for $70 \mathrm{~cm}$ height) with respect to the bare soil condition. Moreover, as shown by the results reported in Figure 7 and Table 4, no particular difference between the vegetation height of 70 and $140 \mathrm{~cm}$ has been noted in terms of soil erosion, which is probably due to the $70 \mathrm{~cm}$ vegetation height that already represents a configuration of maximum efficiency for the reduction of the kinetic energy of rain.

Our results confirm that the use of MC1 represents an effective method against hillslope erosion. Future research work is already ongoing with the aim to compare the performance of $\mathrm{MC} 1$ to other vegetation covers.

Author Contributions: Conceptualization, C.A., A.P., and S.G.; data gathering and field investigation, C.A., C.Z., and A.P.; methodology, C.A., F.T., C.Z., and M.C.; data processing, A.P. and C.A.; writingoriginal draft preparation S.G., C.B., C.A., M.C., F.T., and A.P.; figures and tables, C.A.; writingreview and editing of the final document by all authors; funding acquisition, S.G., M.C., and C.B. All authors have read and agreed to the published version of the manuscript.

Funding: This work was supported by the Italian Ministry for Ecological Transition (Ministero della Transizione Ecologica-Direzione Generale per la sicurezza del suolo e dell'Acqua-SUA), through the Law 5/1/2017 No. 4 "Interventi per il sostegno della formazzione e della ricercar nelle scienzegeologiche, per progetti di ricercar finallizzati alla previsione e alla prevenzione dei rischi geologici".

Institutional Review Board Statement: Not applicable.

Informed Consent Statement: Not applicable.

Data Availability Statement: The data presented in this study are openly available at https:/ drive. google.com/drive/folders/1Zloz0fbhTKJmhRaKvbbjzPHAGta9odhJ?usp=sharing, accessed on 1 May 2021.

Acknowledgments: The authors gratefully acknowledge the support received during the performed tests by Giulia Orrù, David Busetti, Roberto Giulianelli, Antonio Perillo, and Angelo Orlando.

Conflicts of Interest: The authors declare no conflict of interest.

\section{References}

1. Grimm, M.; Jones, R.; Montanarella, L. Soil Erosion Risk in Europe; European Communities: Napoli, Italy, 2001.

2. Kibblewhite, M.G.; Miko, L.; Montanarella, L. Legal frameworks for soil protection: Current development and technical information requirements. Curr. Opin. Environ. Sustain. 2012, 4, 573-577. [CrossRef] 
3. European Commission 2006a: Communication from the Commission to the Council, the European Parliament, the European Economic and Social Committee and the Committee of the Regions-Thematic Strategy for Soil Protection [SEC(2006)620] [SEC(2006)1165]/* COM/2006/0231 final. Available online: http:/ / ec.europa.eu/environment/soil/three_en.htm (accessed on 24 March 2021).

4. European Commission 2006b: Proposal for a Directive of the European Parliament and of the Council Establishing a Framework for the Protection of Soil and Amending Directive 2004/35/EC/* COM/2006/0232 final—COD 2006/0086 13. Available online: http:/ / ec.europa.eu/environment/soil/index_en.htm (accessed on 15 February 2021).

5. European Commission. Guidelines on Best Practice to Limit, Mitigate or Compensate Soil Sealing; Publications Office of the European Union: Luxembourg, 2012; Available online: http://ec.europa.eu/environment/soil/pdf/guidelines/pub/soil_en.pdf (accessed on 18 January 2021).

6. United Nations Convention to Combat Desertification. The Economics of Desertification, Land Degradation and Drought: Methodologies and Analysis for Decision-Making. In Proceedings of the UNCCD 2nd Scientific Conference, Bonn, Germany, 9-12 April 2013.

7. Keesstra, S.; Mol, G.; De Leeuw, J.; Okx, J.; Molenaar, C.; De Cleen, M.; Visser, S. Soil-Related Sustainable Development Goals: Four Concepts to Make Land Degradation Neutrality and Restoration Work. Land 2018, 7, 133. [CrossRef]

8. Adhikari, K.; Hartemink, A.E. Linking soils to ecosystem services-A global review. Geoderma 2016, 262, 101-111. [CrossRef]

9. Recanatesi, F.; Petroselli, A.; Ripa, M.N.; Leone, A. Assessment of stormwater runoff management practices and BMPs under soil sealing: A study case in a peri-urban watershed of the metropolitan area of Rome (Italy). J. Environ. Manag. 2017, 201, 6-18. [CrossRef]

10. Recanatesi, F.; Petroselli, A. Land Cover Change and flood risk in a peri-urban environment of the Metropolitan area of Rome (Italy). Water Resour. Manag. 2020, 34, 4399-4413. [CrossRef]

11. Pellicani, R.; Argentiero, I.; Manzari, P.; Spilotro, G.; Marzo, C.; Ermini, R.; Apollonio, C. UAV and Airborne LiDAR Data for Interpreting Kinematic Evolution of Landslide Movements: The Case Study of the Montescaglioso Landslide (Southern Italy). Geosciences 2019, 9, 248. [CrossRef]

12. Apollonio, C.; Balacco, G.; Novelli, A.; Tarantino, E.; Piccinni, A.F. Land Use Change Impact on Flooding Areas: The Case Study of Cervaro Basin (Italy). Sustainability 2016, 8, 996. [CrossRef]

13. Annis, A.; Nardi, F.; Petroselli, A.; Apollonio, C.; Arcangeletti, E.; Tauro, F.; Belli, C.; Bianconi, R.; Grimaldi, S. UAV-DEMs for Small-Scale Flood Hazard Mapping. Water 2020, 12, 1717. [CrossRef]

14. Luo, H.; Zhao, T.; Dong, M.; Gao, J.; Peng, X.; Guo, Y.; Wang, Z.; Liang, C. Field studies on the effects of three geotextiles on runoff and erosion of road slope in Beijing, China. Catena 2013, 109, 150-156. [CrossRef]

15. Hajigholizadeh, M.; Melesse, A.M.; Fuentes, H.R. Erosion and Sediment Transport Modelling in Shallow Waters: A Review on Approaches, Models and Applications. Int. J. Environ. Res. Public Health 2018, 15, 518. [CrossRef]

16. Pimentel, D.; Harvey, C.; Resosudormo, P.; Sinclair, K.; Kurz, D.; McNair, M.; Crist, S.; Shpritz, L.; Fitton, L.; Saffouri, R.; et al Environmental and economic costs of soil erosion and conservation benefits. Science 1995, 267, 1117-1123. [CrossRef] [PubMed]

17. Gallart, F.; Llorens, P.; Latron, J. Studying the role of old agricultural terraces on runoff generation in a Mediterranean small mountainous basin. J. Hydrol. 1994, 159, 291-303. [CrossRef]

18. Morgan, R.P.C. Soil Erosion and Conservation; John Wiley \& Sons: Hoboken, NJ, USA, 2009.

19. Hamdan, J.; Burnham, C.; Ruhana, B. Degradation effect of slope terracing on soil quality for Elaeis guineensis Jacq.(oil palm) cultivation. Land Degrad. Dev. 2000, 11, 181-193. [CrossRef]

20. Bertolini, D.; Galetti, P.A.; Drugowich, M.I. Tipos e formas de terraços. In Simpósio Sobre Terraceamento Agrícola, Campinas, SP. Anais; Fundação Cargill: Campinas, Brazil, 1989; pp. 79-98.

21. Dorren, L.; Rey, F. A review of the effect of terracing on erosion. In Briefing Papers of the 2nd SCAPE Workshop; Scape: Cinque Terre, Italy, 2004; pp. 97-108.

22. Bunch, R.; López, G. Soil Recuperation in Central America: Sustaining Innovation after Intervention; Gatekeeper Series; International Institute for Environment and Development (RU): London, UK, 1995; Volume 55, 18p.

23. Florineth, F. Stabilization of gullies with soil-Bioengineering methods in the Alps and in Nepal. In Gully Erosion under Global Change; Li, Y., Poisen, J., Valentin, C., Eds.; Sichuan Science and Technology Press: Chengdu, China, 2004; pp. 315-339.

24. Lammeraner, W.; Rauch, H.P.; Laaha, G. Implementation and monitoring of soil bioengineering measures at a landslide in the Middle Mountains of Nepal. Plant Soil 2005, 278, 159-170. [CrossRef]

25. Petrone, A.; Preti, F. Suitability of soil bio-engineering techniques in Central America: A case study in Nicaragua. Hydrol. Earth Syst. Sci. 2008, 12, 1241-1248. [CrossRef]

26. Preti, F.; Giadrossich, F. Root reinforcement and slope bioengineering stabilization by Spanish Broom (Spartium junceum L.). Hydrol. Earth Syst. Sci. 2009, 13, 1713-1726. [CrossRef]

27. Petrone, A.; Preti, F. Soil bio-engineering for risk mitigation and environmental restoration in a humid tropical area. Hydrol. Earth Syst. Sci. 2010, 14, 239-250. [CrossRef]

28. Baumhardt, R.L.; Stewart, B.A.; Sainju, U.M. North American Soil Degradation: Processes, Practices, and Mitigating Strategies. Sustainability 2015, 7, 2936-2960. [CrossRef]

29. Zhang, X.P.; Zhang, L.; McVicar, T.R.; Van Niel, T.G.; Li, L.T.; Li, R.; Yang, Q.; Wei, L. Modelling the impact of afforestation on average annual streamflow in the Loess Plateau, China. Hydrol. Process. 2008, 22, 1996-2004. [CrossRef] 
30. Tron, S.; Dani, A.; Laio, F.; Preti, F.; Ridolfi, L. Mean root depth estimation at landslide slopes. Ecol. Eng. 2014, 69, 118-125. [CrossRef]

31. Evette, A.; Labonne, S.; Rey, F.; Liebault, F.; Jancke, O.; Girel, J. History of bioengineering techniques for erosion control in rivers in Western Europe. Environ. Manag. 2009, 43, 972. [CrossRef]

32. Maxwald, M.; Crocetti, C.; Ferrari, R.; Petrone, A.; Rauch, H.P.; Preti, F. Soil and Water Bioengineering Applications in Central and South America: A Transferability Analysis. Sustainability 2020, 12, 10505. [CrossRef]

33. Broda, J.; Przybyło, S.; Kobiela-Mendrek, K.; Biniaś, D.; Rom, M.; Grzybowska-Pietras, J.; Laszczak, R. Biodegradation of sheep wool geotextiles. Int. Biodeterior. Biodegrad. 2016, 115, 31-38. [CrossRef]

34. Bresci, E.; Preti, F. An historical survey on the evolution of some forest watershed management techniques (Part II: Stream channel works). J. Agric. Eng. 2010, 41, 13-22.

35. Bhattacharyya, R.; Smets, T.; Fullen, M.A.; Poesen, J.; Booth, C.A. Effectiveness of geotextiles in reducing runoff and soil loss: A synthesis. Catena 2010, 81, 184-195. [CrossRef]

36. Maneecharoen, J.; Htwe, W.; Bergado, D.T.; Baral, P. Ecological erosion control by limited life geotextiles (LLGs) as well as with Vetiver and Ruzi grasses. Indian Geotech. J. 2013, 43, 388-406. [CrossRef]

37. Alvarez-Mozos, J.; Abad, E.; Goni, M.; Gimenez, R.; Campo, M.A.; Diez, J.; Casali, J.; Arive, M.; Diego, I. Evaluation of erosion control geotextiles on steep slopes. Part 2: Influence on the establishment and growth of vegetation. Catena 2014, 121, 195-203. [CrossRef]

38. Giménez-Morera, A.; Ruiz-Sinoga, J.D.; Cerdà, A. The impact of cotton geotextiles on soil and water losses from Mediterranean rainfed agricultural land. Land Degrad. Dev. 2010, 21, 210-217. [CrossRef]

39. Guerra, A.; Bezerra, J.; Fullen, M.A.; Mendonça, J.; Jorge, M. The effects of biological geotextiles on gully stabilization in São Luís, Brazil. Nat. Hazards 2015, 75, 2625-2636. [CrossRef]

40. Guerra, A.J.T.; Fullen, M.A.; Jorge, M.d.C.O.; Bezerra, J.F.R.; Shokr, M.S. Slope processes, mass movement and soil erosion: A review. Pedosphere 2017, 27, 27-41. [CrossRef]

41. Smets, T.; Poesen, J.; Bhattacharyya, R.; Fullen, M.A.; Subedi, M.; Booth, C.A.; Kertesz, A.; Toth, A.; Szalai, Z.; Jakab, G.; et al. Evaluation of biological geotextiles for reducing runoff and soil loss under various environmental conditions using laboratory and field plot data. Land Degrad. Dev. Spec. Issue 2011, 22, 480-494. [CrossRef]

42. Smets, T.; Poesen, J.; Fullen, M.A.; Booth, C.A. Effectiveness of palm and simulated geotextiles in reducing run-off and inter-rill erosion on medium and steep slopes. Soil Use Manag. 2007, 23, 306-316. [CrossRef]

43. Vishnudas, S.; Savenije, H.H.G.; Van der Zaag, P.; Anild, K.R. Coir geotextile for slope stabilization and cultivation-A case study in a highland region of Kerala, South India. Phys. Chem. Earth Parts A/B/C 2012, 47-48, 135-138. [CrossRef]

44. Tauro, F.; Cornelini, P.; Grimaldi, S.; Petroselli, A. Field studies on the soil loss reduction effectiveness of three biodegradable geotextiles. J. Agric. Eng. 2018, 49, 117-123. [CrossRef]

45. Smets, T.; Poesen, J.; Langhans, C.; Knapen, A.; Fullen, M.A. Concentrated flow erosion rates reduced through biological geotextiles. Earth Surf. Process. Landf. 2009, 34, 493-502. [CrossRef]

46. Kalibová, J.; Jačka, L.; Petrů, J. The effectiveness of jute and coir blankets for erosion control in different field and laboratory conditions. Solid Earth 2016, 7, 469-479. [CrossRef]

47. Kalibová, J.; Petrů, J.; Jačka, L. Impact of rainfall intensity on the hydrological performance of erosion control geotextiles. Environ. Earth Sci. 2017, 76, 429. [CrossRef]

48. Mitchell, D.J.; Barton, A.P.; Fullen, M.A.; Hocking, T.J.; Zhi, W.B.; Yi, Z. Field studies of the effects of jute geotextiles on runoff and erosion in Shropshire, UK. Soil Use Manag. 2003, 19, 182-184. [CrossRef]

49. Jankauskas, B.; Jankauskiene, G.; Fullen, M. Soil conservation on road embankments using palm-mat geotextiles: Field studies in Lithuania. Soil Use Manag. 2012, 28, 266-275. [CrossRef]

50. Smets, T.; Borselli, L.; Poesen, J.; Torri, D. Evaluation of the EUROSEM model for predicting the effects of erosion-control blankets on runoff and interrill soil erosion by water. Geotext. Geomembr. 2011, 29, 285-297. [CrossRef]

51. EUROSEM-2010: European Soil Erosion Model. 2010. Release 2010. Available online: https: / www.lorenzo-borselli.eu/eurosem/ (accessed on 25 April 2021).

52. Cecconi, M.; Pane, V.; Napoli, P.; Zarotti, C. Mechanical and hydraulic effects of deep roots planting on slope stability. In Proceedings of the TC 215 ISSMGE International Symposium on "Coupled Phenomena in Environmental Geotechnics (CPEG) From Theoretical and Experimental Research to Practical Applications", Torino, Italy, 1-3 July 2013; CRC Press Taylor \& Francis Group: Boca Raton, FL, USA, 2013; Volume 1, pp. 533-540, ISBN 9781138000605.

53. Cecconi, M.; Napoli, P.; Pane, V. Effects of soil vegetation on shallow slope instability. Environ. Geotech. 2015, 2, 130-136. [CrossRef]

54. Rocco, M.V.; Cassetti, G.; Gardumi, F.; Colombo, E. Exergy Life Cycle Assessment of soil erosion remediation technologies: An Italian case study. J. Clean. Prod. 2016, 112, 3007-3017. [CrossRef]

55. Tauro, F.; Petroselli, A.; Fiori, A.; Romano, N.; Rulli, M.C.; Porfiri, M.; Palladino, M.; Grimaldi, S. "Cape Fear"—A Hybrid Hillslope Plot for Monitoring Hydrological Processes. Hydrology 2017, 4, 35. [CrossRef]

56. Esteves, M.; Faucher, X.; Galle, S.; Vauclin, M. Overland flow and infiltration modelling for small plots during unsteady rain: Numerical results versus observed values. J. Hydrol. 2000, 228, 265-282. [CrossRef] 
57. Pérez-Latorre, F.J.; de Castro, L.; Delgado, A. A comparison of two variable intensity rainfall simulators for runoff studies. Soil Tillage Res. 2010, 107, 11-16. [CrossRef]

58. Riley, S.J.; Hancock, F. A rainfall simulator for hydrologic and erosion experiments on mines, with an example of its applications at Ranger Uranium Mine, Northern Territory, Australia. Aust. Inst. Min. Metall. Proc. 1997, 1, 3-8.

59. Grimaldi, S.; Petroselli, A.; Baldini, L.; Gorgucci, E. Description and preliminary results of a 100 square meter rain gauge. J. Hydrol. 2018, 556, 827-834. [CrossRef]

60. Petroselli, A.; Tauro, F.; Grimaldi, S. Investigating runoff formation dynamics: Field observations at Cape Fear experimental plot. Environ. Monit Assess. 2019, 191, 642. [CrossRef]

61. Gray, D.H.; Ohashi, H. Mechanics of fiber reinforcement of sand. J. Geotech. Eng. 1983, 109, 335-353. [CrossRef]

62. Hemmati, S.; Modaressi, A. Study of the stability of unsaturated slopes under the effects of infiltration taking into account the vegetation. In Proceedings of the 18th International Conference on Soil Mechanics and Geotechnical Engineering, Paris, France, 2-6 September 2013; pp. 1117-1120.

63. Wang, K.; Lee, C. Brief mechanical analysis of bioengineering techniques for slope protection. Chin. J. Rock Mech. Eng. 1998, 17, 687-691.

64. $\mathrm{Wu}, \mathrm{T} . \mathrm{H}$. Root reinforcement of soil: Review of analytical models, test results, and applications to design. Can. Geotech. J. 2013, 50, 259-274. [CrossRef]

65. Abe, K.; Ziemer, R. Effect of tree roots on shear zone: Modeling reinforced shear stress. Can. J. For. Res. 1991, $21,1012-1019$. [CrossRef]

66. Feddes, R.A.; Hoff, H.; Bruen, M.; Dawson, T.; De Rosnay, P.; Dirmeyer, P.; Jackson, R.B.; Kabat, P.; Kleidon, A.; Lilly, A.; et al. Modelling root-water uptake in hydrological and climate models. Bull. Am. Meteorol. Soc. 2001, 82, 2797-2809. [CrossRef]

67. Gulizia, J.P.; Downs, K.M. A Review of Kudzu's Use and Characteristics as Potential Feedstock. Agriculture 2019, 9, 220. [CrossRef]

68. Chau, N.L.; Chu, L.M. Fern cover and the importance of plant traits in reducing erosion on steep soil slopes. Catena 2017, 151, 98-106. [CrossRef]

69. Stanchi, S.; Zecca, O.; Hudek, C.; Pintaldi, E.; Viglietti, D.; D’Amico, M.E.; Colombo, N.; Goslino, D.; Letey, M.; Freppaz, M. Effect of Soil Management on Erosion in Mountain Vineyards (N-W Italy). Sustainability 2021, 13, 1991. [CrossRef]

70. Biddoccu, M.; Opsi, F.; Cavallo, E. Relationship between runoff and soil losses with rainfall characteristics and long-term soil management practices in a hill vineyard (Piedmont, NW Italy). Soil Sci. Plant Nutr. 2014, 60, 92-99. [CrossRef]

71. Mohamadi, M.A.; Kavian, A. Effects of rainfall patterns on runoff and soil erosion in field plots. Int. Soil Water Conserv. Res. 2015, 3, 273-281. [CrossRef]

72. Wischmeier, W.H.; Smith, D.D. Predicting Rainfall Erosion Losses: A Guide to Conservation Planning; U.S. Department of Agriculture: Washington, DC, USA, 1978. 